\title{
A Comparison Study of Biology of Hepatitis C Virus (HCV), Human Immunodeficiency Virus (HIV) and Ebola Virus (EbV)
}

\author{
Chetan Datta Poduri \\ Department of Biotechnology (BT), SreeNidhi Institute of Science \& Technology (SNIST), India
}

Copyright $(2016$ by authors, all rights reserved. Authors agree that this article remains permanently open access under the terms of the Creative Commons Attribution License 4.0 International License

\begin{abstract}
In the past there were at least 23 epidemics with Ebola virus (EbV). Presently there are pandemics with Hepatitis $\mathrm{C}$ virus (HCV) and Human Immunodeficiency virus (HIV). The recent epidemic of EbV has taken an year to get contained. Infections with $\mathrm{HCV}$ and HIV are continuing to increase. At present, except for $\mathrm{EbV}$, neither $\mathrm{HCV}$ nor HIV have a vaccine to prevent future infections. Here, a snapshot of the three viruses with regard to their characteristics and prevalence (both global and Indian) are generated with an emphasis to study the infection dynamics of these three RNA viruses in relation to each other. An emphasis is made towards the common or shared features of the three viruses.
\end{abstract}

Keywords HCV, HIV, Ebola, Characteristics, Prevalence

\section{Introduction}

Three RNA viral infections of humans - hepatitis c virus (HCV), human immunodeficiency virus (HIV) and Ebola virus $(\mathrm{EbV})$ - are wrecking havoc on the mankind. Complicating this scenario is the absence of effective vaccines to prevent future infections with these viruses. Additionally, the best therapeutic strategy for managing patients with any of these three viral infections is to provide supportive care to the affected. Various characteristics of the three viruses are compared in Table 1. 
Table 1. Comparison of characteristics of Hepatitis C virus (HCV), Human Immunodeficiency Virus (HIV) -1/-2 and Ebola viruses.

\begin{tabular}{|c|c|c|c|c|}
\hline Virus $\rightarrow$ & $\begin{array}{l}\text { Hepatitis C virus } \\
\text { (HCV) }\end{array}$ & $\begin{array}{l}\text { Human } \\
\text { Immunodeficiency virus } \\
\text { (HIV) }-1\end{array}$ & $\begin{array}{l}\text { Human } \\
\text { Immunodeficiency Virus } \\
\text { (HIV) }-\Omega\end{array}$ & Ebola Virus (Ebv) \\
\hline Discovery & 1989 & 1983 & 1986 & 1976 \\
\hline First Indian Report & 1992 & 1986 & 1991 & 3014 \\
\hline Family & Flaviviridae & Retroviridae & Retroviridae & Filouridae \\
\hline Gemus & Hepacivirus & Lentivirus & Lentivirus & Ebolat like Viruses \\
\hline Natural Hosts & Vertebrates & Vertebrates & Vertebrates & Vertebrates \\
\hline \multicolumn{5}{|c|}{ Characteristic/Property } \\
\hline Particle & $\begin{array}{l}\text { Presumed } \\
\text { Ioosahedron }\end{array}$ & Spherical - pleom rphic & Spherical - pleomorphic & Pleomorphic \\
\hline Size & $40-60 \mathrm{~nm}$ & 8o-10onm & $80-100 \mathrm{~nm}$ & $80 \times$ g7onm \\
\hline Genome & RNA/linear & RNA/dimer & RNA/dimer & RNA/linear \\
\hline Sense & + & + & + & $(-\mathrm{we}$ \\
\hline Segmented & No & No & No & No \\
\hline Length & $\sim 9.4 \mathrm{~kb}$ & $\sim 10 \mathrm{~kb}$ & $\sim 10 \mathrm{~kb}$ & $\sim 11 \mathrm{~kb}$ \\
\hline Copies & One & Tho & Tho & One \\
\hline ORF & $\begin{array}{l}\text { One/ Alternate frame } \\
\text { reported }\end{array}$ & 9 & 10 & One \\
\hline Replication Strategy & Group IV & Group VI & Group VI & Group V \\
\hline Genotypes & $\sim 8$ identified & $\sim$ 8identified & $\sim$ 8identified & $\sim$ 5reported \\
\hline Recombinant forms & Reported & Reported & Reported & To be reported \\
\hline Proteins & 10 & 15 & 17 & $\begin{array}{l}\text { 7(yet to be } \\
\text { oompletely } \\
\text { characterized) }\end{array}$ \\
\hline Structural Proteins & 3 & 2 & 2 & -- \\
\hline Non-structural & 7 & 13 & 15 & -- \\
\hline Receptor & $\mathrm{LDL} / \mathrm{CD} 81(?)$ & $\mathrm{CD}_{4}$ & $\mathrm{CD}_{4}$ & $\begin{array}{l}\text { DC-SIGN/DC- } \\
\text { SIGNR (?) }\end{array}$ \\
\hline $\begin{array}{c}\text { Co-receptor/assistor } \\
\text { molecules }\end{array}$ & $\begin{array}{c}\text { Cholesterol } \\
\text { transporter } \\
\text { Niemann-Pick } C_{1} \\
(\mathrm{NPC})(?)\end{array}$ & $\mathrm{CXCR}_{4} \& \mathrm{OCR} 5$ & $C_{C R} 48: O C R 5$ & $\begin{array}{c}\text { Cholesterol } \\
\text { transporter } \\
\text { Niemann-Pick } C_{1} \\
\text { (NPC1) (?) }\end{array}$ \\
\hline Transmission & $\begin{array}{l}\text { Nosoon mial, } \\
\text { ontaminated body } \\
\text { fluids and organs }\end{array}$ & $\begin{array}{l}\text { Contaminated body fludids, } \\
\text { Majority bysexual } \\
\text { transmission }\end{array}$ & $\begin{array}{l}\text { Contaminated body fluids, } \\
\text { Majority bysexual } \\
\text { transmission }\end{array}$ & $\begin{array}{c}\text { Vector-bome, Sexual. } \\
\text { Humars dead-end } \\
\text { hosts }\end{array}$ \\
\hline Vector & -- & -- & -- & Mosquitoes \\
\hline Natural Reservoir & Primates (?) & Primates (?) & Primates (?) & Fruitbats \\
\hline Clinical Disease & $\begin{array}{l}\text { Hepatitis and } \\
\text { associated liver } \\
\text { disorders }\end{array}$ & AIDS & AIDS & $\begin{array}{l}\text { Majority } \\
\text { asymptomatic, } \\
\text { Neuro logic } \\
\text { symptoms }\end{array}$ \\
\hline Treatment & TypicallyInterferon & $\mathrm{ART}$ & $\mathrm{ART}$ & $\begin{array}{l}\text { Ebola Supportive } \\
\text { care }\end{array}$ \\
\hline Vaccine & -- & -- & $-\cdot$ & Phase II trials \\
\hline Additional Information & -- & -- & -- & $\begin{array}{c}\text { Category A } \\
\text { bioterrorism } \\
\text { agent }\end{array}$ \\
\hline \multicolumn{5}{|c|}{ 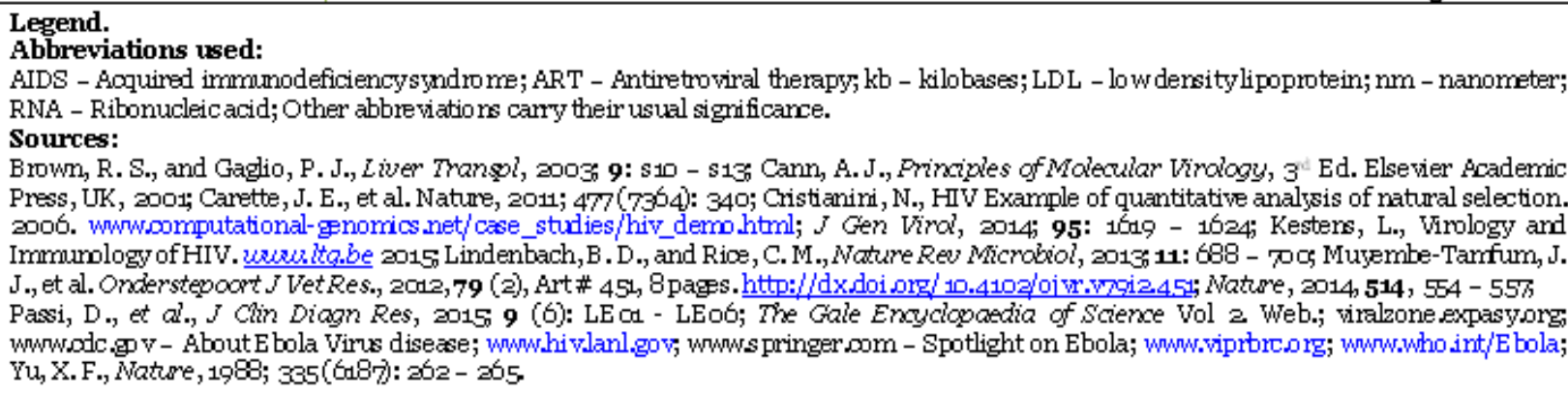 } \\
\hline
\end{tabular}

Despite differences in replication strategies and the pathogenesis patterns of the three viruses, we can easily identify from table 1 that the viruses when compared in pairs have something in common apart from the genome being RNA. This can be depicted as a Venn diagram as in Figure 1. 


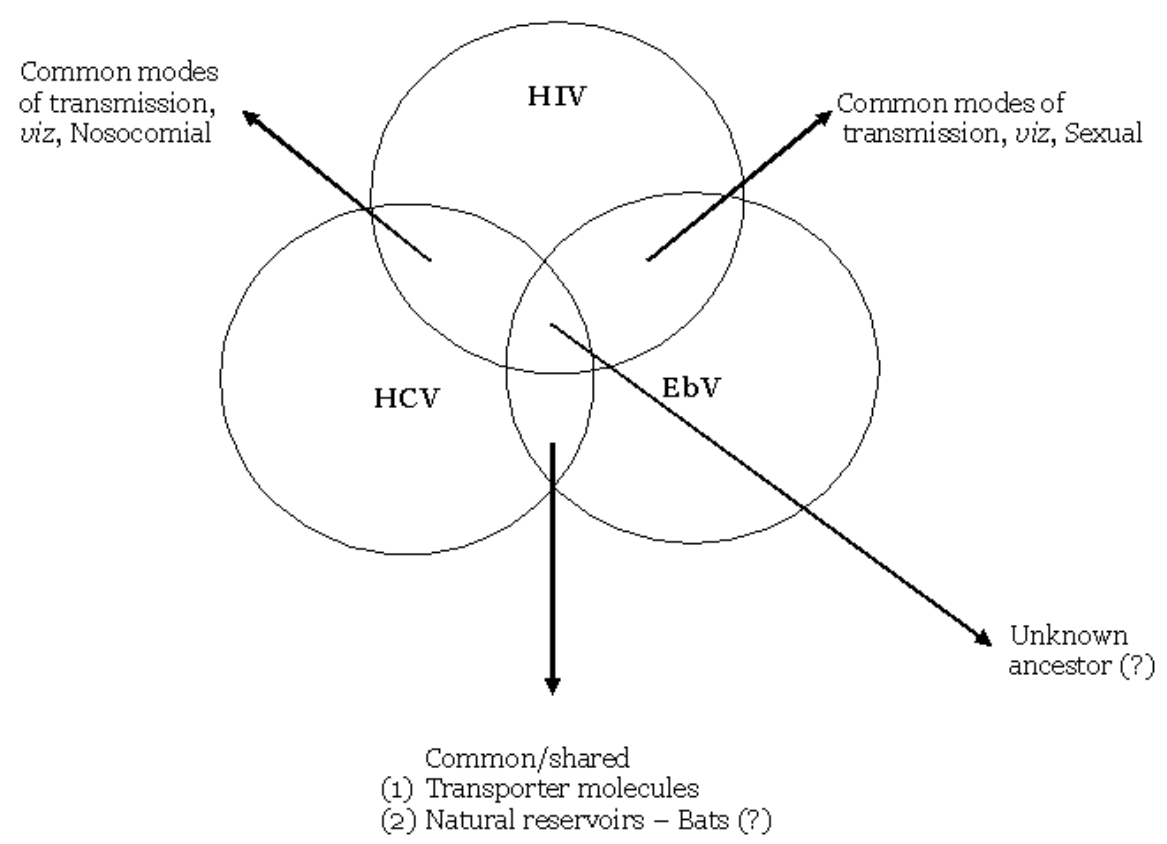

Legend. The overlapping regions identify common/shared properties of the respective viruses. All abbreviations carry their usual significance.

Figure 1. Venn diagram depicting the common aspects of three viruses in the present study - HCV, HIV \& EbV.

\section{Materials and Methods}

Because the three mentioned viruses have RNA as their nucleic acid, and seem to be infecting a large number of human populations, it makes sense to study these three viruses together. With this as the aim, scientific literature was scanned through for prevalence of infection with any of the three viruses since 1976. For this purpose multiple search engines and internet resources were used to access full articles. These include google scholar, PubMed, and Gale's Academic OneFile InfoTrac (provided through author's personal membership of British Council Library, Hyderabad, India). Only those articles for which the author had full-text access were included. Data made available in abstracts for which the author could not have complete article access were not included in the present study. Statistics with regard to the world are collated as Table 2, while Table 3 summarizes similar statistics with regard to India.

Table 2. Global decadal statistics for Hepatitis C virus (HCV), Human Immunodeficiency Virus (HIV) - 1 \& 2, and Ebola virus (EbV).

\begin{tabular}{|c|c|c|c|c|}
\hline \multirow[b]{2}{*}{ Decade } & \multicolumn{4}{|c|}{$\begin{array}{c}\text { Preva lence } \\
\text { (unless indicated all walues are average of walues reported in warious sounos) }\end{array}$} \\
\hline & $\begin{array}{c}\text { Ebola virus } \\
\text { (EbV) }\end{array}$ & $\begin{array}{l}\text { Hepatitis C } \\
\text { virus }(\mathrm{HCV})\end{array}$ & $\begin{array}{c}\text { Human } \\
\text { Immunodeficiency } \\
\text { virus }(\mathrm{HIV})-1\end{array}$ & $\begin{array}{c}\text { Human } \\
\text { Immunodeficiency } \\
\text { virus (HIV) - } 2\end{array}$ \\
\hline $1976-1985$ & 637 & Not discovered & $20,3 \circ 3$ & Not discovered \\
\hline $1986-1995$ & 370 & 122 million & \multicolumn{2}{|c|}{$>3$ million } \\
\hline $1996-2005$ & 832 & 176.85 million & \multicolumn{2}{|c|}{32.2 million (on 2005 ) } \\
\hline $2006-2015$ & 25,987 & 158 million & \multicolumn{2}{|c|}{ 37.7 million (at March, 2015) } \\
\hline
\end{tabular}


Table 3. Indian decadal statistics for Hepatitis $\mathrm{C}$ virus (HCV), Human Immunodeficiency Virus (HIV) - $1 \& 2$, and Ebola virus (EbV)

\begin{tabular}{|c|c|c|c|c|}
\hline \multirow[b]{2}{*}{ Decade } & \multicolumn{4}{|c|}{$\begin{array}{l}\text { Prevalence } \\
\text { (unless indicated all walues are average of walues reported in warious sounos) }\end{array}$} \\
\hline & $\begin{array}{l}\text { Ebola virus } \\
\text { (Eb V) }\end{array}$ & $\begin{array}{l}\text { Hepatitis } \mathrm{C} \\
\text { virus }(\mathrm{HCV})\end{array}$ & $\begin{array}{c}\text { Human } \\
\text { Immunodeficiency } \\
\text { virus (HIV) - 1 }\end{array}$ & $\begin{array}{c}\text { Human } \\
\text { Immunodeficiency } \\
\text { virus }(\text { HIV })-\mathbf{2}\end{array}$ \\
\hline $1976-1985$ & $\circ$ & Not discovered & 0 & Not disoovered \\
\hline $1986-1995$ & $\circ$ & $\begin{array}{l}6.69 \text { million } \\
\text { (estimated) }\end{array}$ & \multicolumn{2}{|c|}{2108 (people with AIDS) } \\
\hline $1996-2005$ & $\circ$ & $\begin{array}{c}9,783, \circ 00 \text { (on } \\
2004)\end{array}$ & \multicolumn{2}{|c|}{5.1 million (on 2003) } \\
\hline $2006-2015$ & 1 & $\begin{array}{c}18,216,960 \text { (on } \\
2010)\end{array}$ & \multicolumn{2}{|c|}{2.5 million $(2005) \rightarrow 4.4$ million (at 2013 ) } \\
\hline
\end{tabular}

Note: NACO started AIDS/HIV surveillance in 1998, prior to which screening at various limited designated places in India was done by ICMR since 1986.

\section{Sources:}

Acharya, S. K., et al., Natl Med J India, 2006; 19 \# 4: 203; Bagœhi, S., BMU 2014; 4; 349: g7328; Factsheets on HIV/ADIS and sexually transmitted infections. India. Update 2004. www. who.int; Hepatitis C: surveillance and control. Global Alert and Response (GAR). World Health Organization. 2015. Web. www.who.int; HVV Data. Updated 18-Nov-2015. Accessed 18-Nov-2015. Nacogov.in; Lavanchy, D., Clin Microbiol Infect, 2011; 17: 107 - 115; Ramesh, R., et al., J Gastroenterol Hepatol, 1992; 7: 393; Shepard, C. W., et al., Lancet Infect Dis, 2005; 5: $55^{8}-567$, www.avert.org.

\section{Observations, Results \& Discussion}

Readers must note at this stage that whereas EbV was discovered in 1976, only in the latter half of 1980s were the other two viruses (HCV \& HIV) discovered. While HIV-1 was discovered in 1983, HIV-2 was discovered in 1986. 1989 saw the discovery of HCV. Therefore prior to 1976 there were no reports of any of these three viruses. However, some information with regard to $\mathrm{HCV}$ might be available as documented under the old name Post transfusion non-A, non-B hepatitis (PT-NANBH). Again with the discovery of two more viruses the GBV-C in 1995 [1], and transfusion transmitted virus (TTV) in 1997 [2], cases of PT-NANBH cannot be exclusively classified as HCV. Therefore, certain amount of doubt exists with regard to the same and hence 1976 was taken as the starting point for generating information in tables 2 and 3.

From Table 1 it is readily observable that both HCV and $\mathrm{EbV}$ share cholesterol transporter as one assistor molecule for the entry of their respective viral particles into cells [3, 4]. It must be noted at this stage that various authors have noted that $\mathrm{HCV}$ appears to be an opportunistic pathogen in HIV infection. Needless-to-say, at present $4-5$ million people living with HIV/AIDS are also co-infected with $\operatorname{HCV}[5,6]$. Also, all the three viruses seem to share at least one common mode of transmission that of transmission from humans to humans via contaminated body fluids and contaminated organs used for transplantation. In other words, these viruses seem to share at least nosocomial mode of transmission. When considered in pairs, HIV and EbV share an additional sexual mode of transmission.
Furthermore, at least two reports suggest that bats might be one possible natural reservoir for $\operatorname{HCV}[7,8]$. Incidentally, bats are the natural reservoirs for EbV (Table 1). Despite the genera of bats, the very observation that this animal is the reservoir for $\mathrm{HCV}$ and $\mathrm{EbV}$ has potential implications given the fact that recombination among RNA viruses is documented to be a relatively common event. And inter-genera crossings among bats might be occurring naturally whence a few bats may harbor both the viruses simultaneously. Therefore, there is a clear need to study infection dynamics of HCV, HIV and EbV together. Such a study would involve simultaneous monitoring of anti-viral antibodies against $\mathrm{HCV}, \mathrm{HIV}$ and $\mathrm{EbV}$ in the patient sera. With the increased acceptance of antibody diagnosis of viral infections, whereas cross-reacting antibodies may give a false picture, a true snapshot is obtained only when the corresponding antigen is isolated from the patient samples. However, it may be noted that for viruses like HCV and HIV, perhaps the only acceptable antigen isolation for routine testing is in nucleic acid tests (NAT) in the form of reverse transcription polymerase chain reaction (RT-PCR) which can be made quantitative in many cases. Also, identifying the infecting genotype, at least for research purposes, for monitoring the evolutionary dynamics of the virus becomes an essential element when HCV is involved.

In addition to what has been described above, although EbV seems to survive in the wild in (fruit) bats, a number of other animals have been shown to harbor the virus. These include guinea pigs, goats, horses, dogs [9] and pigs (Sus scrofa) [10]. However, among these, as Allela et al suggest, perhaps only dogs seem to be naturally and 
asymptomatically infected with EbV [9]. Put simply, the entire natural host range of EbV is yet to be mapped; and primary transmission seem to be occurring in animals, with animal-to-human or human-to-human transmission representing a secondary transmission for EbV. Given these observations, it could be possible that the virus might be still evolving and may likely to acquire novel characteristics. Partial evidence for this statement comes from the observation that the infecting strains of $\mathrm{EbV}$ in DRC and West Africa appear to be different in the recent epidemic of Ebola in Africa [11]. Similar arguments can be extrapolated to $\mathrm{HCV}$ and HIV with specific reference to the natural host range.

Till date only co-infection cases of either HCV - HIV, $\mathrm{HIV}$ - EbV and/or EbV - HCV have been reported. Although specific co-infection cases of EbV and $\mathrm{HCV}$ are yet to be identified, efforts by earlier researchers in this direction does indicate the possibility towards such infections [12]. The possibility of HIV-EbV co-infection arises as a consequence of isolation of HIV from archival samples of EbV in retrospective studies [13]. However, Parkes-Ratanshi et al do report the presence of viral hemorrhagic fever (VHF), albeit of a varied etiology, in patients visiting an HIV centre [14]. They also mention that such a situation represents on high risk threat in areas with high HIV population. To the best of the author's knowledge reports of super infections with all the three viruses in a single individual are yet to be documented. Despite this, as mentioned earlier, viruses recombining amongst themselves or with other viruses either in the wild within the identified natural carriers or in nosocomial settings when the contaminated body fluids are administered to patients cannot be ruled out entirely. Therefore, even in the absence of any patient specific data or animal studies, compulsory monitoring of all individuals reporting for various ailments to healthcare personnel at least in the Ebola affected countries of Democratic Republic of Congo (DRC), Liberia, Nigeria, Sierra Leone and other potentially threatened African countries becomes essential. Thus, continuous monitoring of sylvatic animals, in addition to determining the complete host range of the three viruses, although a difficult proposition, in the mentioned directions is the need of the hour.

\section{Endnote/Acknowledgements}

Data presented in Tables, and a poster presented by the author at the 14th FAOBMB congress \& 84th SBC (I) meet held at Hyderabad, India between 27th -30 th November, 2015 , share the same data.

The author wishes to acknowledge helpful discussions with colleagues past and present.

Author's mailing address/contact details: Flat - 501, Highlight Haveli, Street - 6, Habsiguda, Hyderabad 500007, Telangana, India. Phone(s): +91-9492891303 \& $+91-9816160830$

\section{List of Abbreviations}

AIDS - Acquired immunodeficiency virus; DRC Democratic Republic of Congo; EbV - Ebola virus; HCV hepatitis $\mathrm{C}$ virus; HIV - Human immunodeficiency virus; NAT - nucleic acid testing; PT-NANBH - Post-transfusion non-A, non-B hepatitis; RNA - Ribonucleic acid; RT-PCR - reverse transcription polymerase chain reaction; TTV Transfusion transmitted virus; VHF - Viral hemorrhagic fever; Other abbreviations carry their usual significance.

\section{REFERENCES}

[1] Simons JN, Pilot-Matias TJ, Leary TP, et al., Identification of two flavivirus-like genomes in the GB hepatitis agent. Proc Natl Acad Sci U S A. 1995; 92:3401e3405.

[2] Nishizawa T, Okamoto H, Konishi K, Yoshizawa H,Miyakawa Y, Mayumi M., A novel DNA virus (TTV) associated with elevated transaminase levels in posttransfusion hepatitis of unknown etiology. Biochem Biophys Res Commun., 1997; 241(1):92e97.

[3] Lupberger, J., Felmlee, D. J., Baumert, T. F., Cholesterol uptake and hepatitis C virus entry. J Hepatol, 2012; 57: 215 217.

[4] Carette, J. E., Raaben, M., Wong, A. C., Herbert, A. S., Obemosterer, G., Mulherkar, N., Ebola virus entry requires the cholesterol transporter Niemann-Pick C1. Nature, 2011; 477 (7364): 340.

[5] Rotman, Y., and Jake Liang, T., Coinfection with hepatitis C virus and human immunodeficiency virus: virological, immunological and clinical outcomes. J Virol, 2009; 83 \# 15: $7366-7374$.

[6] Alter, M. J., Epidemiology of Viral hepatitis and HIV co-infection. J Hepatol, 2006; 44: S6 - S9.

[7] Quan, P-L., et al., Bats are a major natural reservoir for hepaciviruses and pegiviruses. PNAS Early Edition, 2013; www.pnas.org/cgi/doi/10.1073/pnas.1303037110

[8] Pybus, O. G., and Gray, R. R., The virus whose family expanded. Nature, 2013; 498: 310 - 311.

[9] Allela, L., Bourry,O., Pouillot, R., Délicat, A., Yaba, P., Kumulungui, B., Rouquet, P., Gonzalez, J-P., Leroy, E. M., Ebola Virus Antibody Prevalence in Dogs and Human Risk. Emerging Infectious Diseases, 2005; 11 \# 3: 385 - 390.

[10] Weingartl, H. M., Embury-Hyatt1, C., Nfon, C., Leung, A., Smith, G., Kobinger, G., Transmission of Ebola virus from pigs to non-human primates. Scientific Reports, 2012, 2, 811; DOI: $10.1038 /$ srep00811.

[11] Naresh Kumar, C. V. M. N., Sai Gopal, D. V. R., Possible risk of Ebola outbreak in India: how well are we prepared? Current Science, 2014; 107 \# 6: 937.

[12] Bonney, J. H. K., Osei-Kwasi, M., Adiku, T. K., et al., Hospital-based surveillance for viral hemorrhagic fevers and hepatitides in Ghana. PLoS Neglected Tropical Diseases, 2013; 7 \# 9: e2435. doi:10.1371/journal.pntd.0002435. 
[13] Anonymous. 1988. Scientists isolate 'earliest HIV isolate' from 1976 serum sample in Northern Zaire. AIDS Alert 1988, 35 .

[14] Parkes-Ratanshi R, Elbireer A, Mbambu B, Mayanja F,
Coutinho A, et al., Ebola Outbreak Response; Experience and Development of Screening Tools for Viral Haemorrhagic Fever (VHF) in a HIV Center of Excellence Near to VHF Epicentres. PLoS ONE, 2014; 9(7): e100333. doi:10.1371/journal.pone.0100333. 